RESEARCH PAPER

\title{
The Australian tar derby: the origins and fate of a low tar harm reduction programme
}

\author{
W King, S M Carter, R Borland, S Chapman, N Gray
}

Tobacco Control 2003;12(Suppl III):iii61-iii70

See end of article for authors' affiliations

Correspondence to: Bill King, VicHealth Centre for Tobacco Control, The Cancer Council Victoria, 1 Rathdowne Street, Carlton, Vic 3053, Australia; Bill.king@cancervic.org.au

\begin{abstract}
Objective: To document the development of the low tar harm reduction programme in Australia, including tobacco industry responses.

Data sources: Tobacco industry documents, retail tobacco journals, newspapers, medical journals, and Anti-Cancer Council of Victoria (ACCV) newsletters and archival records.

Study selection: Documents on the strategies and knowledge bases of the ACCV, other Australian health authorities, and the tobacco industry.

Results: The ACCV built a durable system for measuring and publicising the tar and nicotine yields of Australian cigarettes and influencing their development. The tobacco industry initially sought to block the development of this system but later appeared to cooperate with it, as is evidenced by the current market dominance of low tar brands. However, behind the scenes, the industry used its substantial knowledge advantage regarding compensatory smoking and its ability to re-engineer cigarettes to gain effective control of the system and subvert the ACCV's objectives.

Conclusions: Replacement of the low tar programme with new means of minimising the harms from cigarette smoking should be a policy priority for the Australian government. This will require regulation, rather than further voluntary agreements, and stringent monitoring of successor programmes will be necessary.
\end{abstract}

\section{CONCEPT: REALLY LOW IN TAR.}

This concept is overwhelmingly embraced [by focus group members], providing the manufacturer can deliver the promise. As one pointed out "if you can get something that's not a slow suicide brand then it's all the better, isn't it?" - Philip Morris Market Research document, 1983.'

Most experiments fail. Usually, that amounts to a setback before eventual success. However, if a large scale experiment is conducted outside laboratory walls and over an extended period of time, the consequences of failure can be serious. In recent years the tobacco control community has been coming to terms with the fact that low tar harm reduction programmes are failed experiments of the latter kind. ${ }^{2}$

The low tar cigarette originated as a tobacco industry response to the "cancer scare"-the upsurge in public concern about the health effects of smoking in the early 1950 s, following the publication of studies providing strong evidence that cigarette smoking causes lung cancer. ${ }^{3}{ }^{4}$ In the wake of the "cancer scare", manufacturers in the USA sought to reassure smokers that their brands were "safer". This was often accomplished by means of comparisons of the tar and nicotine yields of different brands. In the mid 1950s, a fierce competition developed between manufacturers to market the lowest tar and nicotine brand. This became known as the "tar derby". In the 1960s public health authorities in the USA took up the low tar cigarette as a key feature of a harm reduction strategy for those smokers who remained unreceptive to quit messages. Developments in the USA were closely followed in Australia, which became among the first countries in the world to implement a low tar harm reduction programme. Despite initial resistance to low tar cigarettes from the Australian tobacco industry, there has been a massive change to Australian cigarette market since the low tar programme began. Under the current US definition
$(<16 \mathrm{mg}$ tar yield), the Australian market now consists entirely of low tar brands.

In this paper we seek to understand further the causes of the failure of low tar programmes by following the Australian programme from its inception to the present. The Australian low tar programme provides a convenient case study, because it was largely driven by one small, state-based non-governmental organization, the Anti-Cancer Council of Victoria (ACCV). We trace the ACCV's system building efforts, ${ }^{56}$ through which a durable system for measuring and publicising the tar and nicotine yields of Australian cigarettes and influencing their development emerged. We also trace the tobacco industry's counter-efforts, which have arguably led to it gaining effective control of the system and redirecting it for the purpose of providing misleading health reassurances, which have helped to prevent health concerned smokers quitting.

\section{METHOD}

\section{Data sources}

The knowledge bases and strategies of the ACCV and other health authorities were reconstructed from published material, including the ACCV newsletter Victorian Cancer News, newspaper articles, journal articles, and Senate reports. The tobacco industry's public positions were reconstructed from tobacco industry documents, retail tobacconist journals, and

Abbreviations: ACA, Australian Consumers Association; ACCV, AntiCancer Council of Victoria (The Cancer Council Victoria since 2002); AGAL, Australian Government Analytical Laboratory; BAT, British American Tobacco; BATA, British American Tobacco, Australia; BTCA, the British Tobacco Company Australia; CPM, corrected particulate matter; FTC, US Federal Trade Commission; ISO, International Standards Organization; NHMRC, National Health and Medical Research Council, PML, Philip Morris Limited (Australia); TPM, total particulate matter; Wills, WD \& HO Wills Ltd. 
newspaper articles. The industry's knowledge base, private positions and publicly invisible actions were reconstructed using tobacco industry documents.

\section{Search procedure}

A "snowballing" procedure was employed for document searches, proceeding from key terms regarding low tar cigarettes to specific terms, brand names, and industry personnel identified in early searches. More relevant documents were discovered in the Brown and Williamson collection than other collections. This is reflected in the illustrative material presented below.

\section{RESULTS}

Tar testing, cigarette yields, and harm reduction The US Federal Trade Commission/International Standards Organization (FTC/ISO) yield test is a standardised procedure for comparing manufactured cigarettes, using a $35 \mathrm{ml}$ puff, over two seconds, once per minute, until a prescribed butt length is reached (tipping $+3 \mathrm{~mm}$ or $30 \mathrm{~mm}$ minimum in Australia). This test is currently used in Australia to provide consumers with quantitative information about hazardous substances in the smoke of different brands. The results reported are the yields of tar (or corrected particulate matter), nicotine, and carbon monoxide.

The FTC/ISO test originated within the tobacco industry in the "technic of experimental smoking" developed by Bradford, Harlan, and Hanmer in $1936 .^{7}$ They proposed that a successful smoking experiment should sufficiently approximate human smoking for conclusions from in vitro experiments to "admit of interpretation in vivo" and believed their test fulfilled this purpose. However, in 1967, the FTC gave a very different statement of purpose: "[the purpose of the FTC yield test is] not to determine the amount of 'tar' and nicotine inhaled by any human smoker, but rather to determine the amount of 'tar' and nicotine generated when a cigarette is smoked by machine in accordance with the prescribed method." ${ }^{\prime 4}$ No standardised yield test could fail to fulfil such a purpose. However, the underlying purpose of yield testing in a harm reduction programme must be to differentiate less dangerous cigarettes from more dangerous ones. As can be seen in figl, the ACCV originally understood the FTC yield test as "the best available" means of identifying "safer" cigarettes and enabling individual smokers to reduce their health risks. ${ }^{8}$

\section{The Australian low tar campaign begins}

In 1966, EV Keogh, the medical advisor to the ACCV, conceived a harm reduction programme for smokers who were unwilling or unable to quit. The impetus for the programme came from a 1966 US Public Health Service report, which stated: "[ $\mathrm{t}]$ he preponderance of scientific evidence strongly suggests that the lower the tar and nicotine content of cigarette smoke, the less harmful would be the effect." ${ }^{\prime 4}$ It was anticipated, firstly, that individual smokers could reduce their disease risks by choosing a lower tar and nicotine brand and, secondly, that a general reduction of tar and nicotine yields would lead to a lower smoking attributable disease burden at the population level.

Implementing the proposed low tar programme in Australia would entail some major transformations of awareness and attitudes. Before 1966, tar and nicotine yields barely figured for Australian smokers. Instead, the Australian tobacco industry's efforts to allay the fears of "health concerned" smokers took the form of suggestions that filters would solve the "smoking and health problem". ${ }^{9}$ While the Australian Consumers Association had followed the example of Readers Digest and reported the results of a tar test for selected local brands in 1961, ${ }^{10}{ }^{11}$ it did not continue on with a sustained campaign for "safer cigarettes". (It even prevented dissemination of its detailed findings in newspapers, ensuring few smokers became aware of them. ${ }^{12}$ ) Further, no government agency in Australia had publicly expressed concern over the tar and nicotine yields of local cigarettes.

The ACCV's campaign was launched in Victorian Cancer News in $1966 .{ }^{13}$ The ACCV sought to undermine beliefs that filtered cigarettes are safer than unfiltered ones and to build beliefs that low tar cigarettes would be less dangerous. It reported a study of the tar and nicotine yields of 12 popular US brands, conducted by George Moore of the Roswell Park Memorial Institute in New York. Moore found that of three brands with both filtered and unfiltered varieties, the tar yields were higher in the filtered variety in each case and the nicotine yields higher in two cases. However, the ACCV did not advocate turning back to unfiltered cigarettes, because Moore also found that the filtered brands varied greatly in tar

\section{Tar Yields in Australian Cigarettes-New List}

\begin{abstract}
Just to hand is a report on the tar yields in brands of popular Australian cigarettes.

These figures were determined in the Department of Chemistry, Monash University, under a research grant from the Anti-Cancer Council of Victoria. The method of obtaining tar content of tobacco smoke* is the standard method of the U.S. Government's Federal Trade Commission which publishes complete lists for U.S. brands regularly.

The Anti-Cancer Council believes that the greater the tar content in cigarettes smoked the greater the risk of lung cancer to the smoker. Although not an infallible guide, tar levels are at present the best available assessment of the cancer producing properties of cigarettes. For those concerned about the future of Australian tobacco growing, the list below should dispel any worries that it may not be possible to produce low tar brands in Australia.
\end{abstract}

\section{Why is Tar Content Important?}

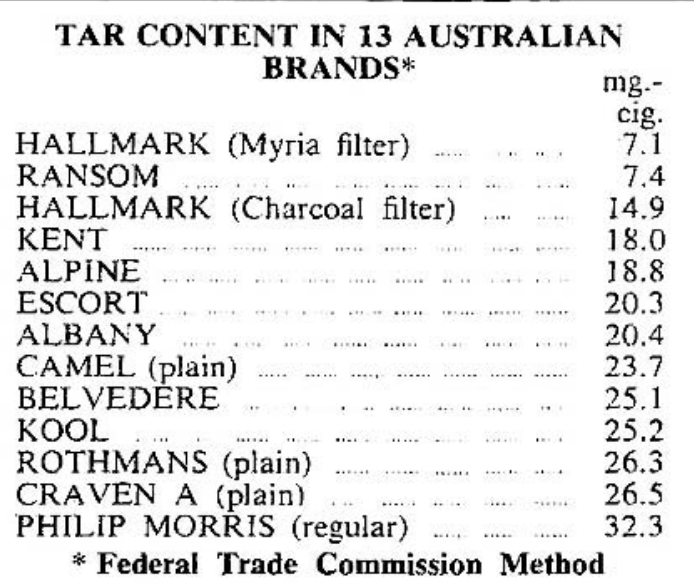

Figure 1 Second Anti-Cancer Council of Victoria tar table and explanatory text, July 1968. 
and nicotine yields (ranging from True ( $16.9 \mathrm{mg}$ tar, $0.79 \mathrm{mg}$ nicotine) to Pall Mall (43.3 mg tar, $2.13 \mathrm{mg}$ nicotine)). While stressing that no cigarette was ever likely to be safe, the ACCV proposed that lower yield brands would be less hazardous. It called on the federal government to make the Department of Health responsible for determining the carcinogenic potential of Australian cigarettes so smokers could make informed choices and the tobacco industry would be motivated to conduct a "safer cigarette war". In the meantime, the ACCV undertook to gain preliminary information on the yields of local brands.

The tobacco industry soon revealed it would not be a willing participant in the proposed low tar programme. In 1967, the retail tobacconist journals presented a case against tar testing and low tar cigarettes. ${ }^{14}{ }^{15} \mathrm{~A}$ variant of the "no proof" argument was raised first: if there is no proven causal link between smoking and disease, there is no valid reason for avoiding exposure to any smoke component. The second argument granted the possibility of a harmful ingredient in cigarette smoke, while raising the possibility of tar and nicotine labelling leading to increased exposures to this ingredient. Three scenarios were presented to persuade readers to take the "potentially increased harm" argument seriously:

(1) The harmful ingredient is carried in the vapour phase, rather than the particulate phase (which gives rise to tar). The author proposed: "The use of 'nicotine and tar' labelling could be dangerous, as it could cause some health-conscious smokers to switch from charcoal-filtered brands (which reduce certain ingredients in the gas phase) to low 'nicotine and tar' brands without charcoal." ${ }^{\prime 15}$

(2) Reduction in nicotine "content" could lead to increased consumption of cigarettes and increased intake of a harmful ingredient that is not part of the nicotine and "tar" contents. ${ }^{15}$

(3) Tar and nicotine labelling could give smokers a false sense of security that their chosen brand is safe, if it is low "tar". 15

The third argument against the ACCV's proposal was that tar testing for consumer information was likely to be the "thin end of the wedge" - that is, it would be just the first step toward regulation ending with smokers' preferred brands removed from the market and replaced with unacceptable new brands. ${ }^{15}$ Consequently, non-health concerned smokers who wanted freedom to smoke whatever they liked could not afford to simply ignore the ACCV's proposals-they would need to actively oppose them.

Given what the tobacco control community now knows about compensatory smoking (that is, changing smoking behaviours with different cigarettes so as to maintain nicotine intakes and changing exposures to certain carcinogens in cigarette smoke), ${ }^{26-18}$ much of the "potentially increased harm" argument looks impressively close to the mark. However, it is debatable whether it should have been recognised in 1967 as something more than an ad hoc argument to defend tobacco industry interests. The industry already had a long track record of being economic with the truth. Further, the "possibly increased harm" argument appeared to serve the industry's apparent commitment to "business as usual". Thus, proponents of the low tar programme had good practical reasons for simply disregarding the argument.

\section{The first ACCV tar test}

In July 1967, the ACCV reported the tar and nicotine yields of 10 popular Australian brands that had been tested at Roswell Park along with 56 US brands. ${ }^{8}$ The Australian brands had an average tar yield of $35 \mathrm{mg}$, ranging from $23-40 \mathrm{mg}$, whereas the US brands had an average tar yield of $25 \mathrm{mg}$, ranging from $8-43 \mathrm{mg}$. Further, 18 US brands had tar yields below the lowest yielding Australian brand, Kent. The ACCV argued these results showed Australian smokers were deprived of the low tar options available to American smokers and this was unacceptable. It also argued that two sources of evidence strongly supported the conclusion that smokers would lower their cancer risks if they down-switched. ${ }^{8}$ Firstly, a number of epidemiological studies had found a dose-response relation between number of cigarettes per day and lung cancer risk. This evidence suggested that lung cancer risk would also be reduced if tar intake per cigarette decreased. Secondly, tarpainting experiments had found the carcinogenicity of tar of specific brands was proportionate with their tar yields.

While acknowledging the possibility that down-switchers could wind up smoking more cigarettes per day, the ACCV took the position that compensatory smoking was unlikely to mean that switching to low tar brands resulted in no reduction in intakes. ${ }^{8}$ It argued:

(1) Smoking is a "psychological habituation", rather than a physical addiction

(2) Situations are an important determinant of smoking frequency

(3) Changes in the tar and nicotine content of cigarettes will not change the situations in which people are accustomed to smoke

(4) Even if smokers do increase their consumption in response to lower tar and nicotine yields, they are unlikely to, say, smoke three times as many low tar cigarettes to obtain their accustomed amounts of tar and nicotine.

The ACCV's concluding claim was that the low tar programme would prove relatively painless for everyone:

We have it in our power to attempt a partial solution to the destruction caused by smoking. Lowering tar content of cigarettes is a practical possibility, which can be effected without serious inconvenience or hardship to any government, business or individual interests.

\section{Waiting can only cost lives. ${ }^{8}$}

It is noteworthy that, in 1967, the ACCV understood smoking in terms of habit, rather than addiction. However, contrary claims were not long in coming from within the fold. Following the ACCV's second tar test in 1968, John Swan, professor of organic chemistry at Monash University (where the testing was conducted), claimed: "Smoking is, after all, not a habit. It is a drug addiction. And drug addicts need help." ${ }^{19}$ By the 1970s, the ACCV was consistently claiming that nicotine is addictive and stating that smoking low tar cigarettes "may weaken the hold of the nicotine addiction", ${ }^{20}$ thus providing a second reason for switching to low tar cigarettes. The alternative possibility - that nicotine addiction may undermine the effectiveness of low tar cigarettes-did not become apparent to the Australian tobacco control community until the late 1970s. ${ }^{2}$

Tobacco industry responses to the first ACCV tar table The tobacco industry sought to discredit the ACCV's first tar table. An editorial in the retail tobacconist journals ${ }^{21}$ claimed that the tests were carried out by "an unnamed organization in the USA" with "no information...published on the procedure used in the tests". It also argued that tar testing was a dubious practice in any circumstances, as tests conducted in different laboratories in the USA found notably 
different yields for the same brands. Thus, the editorial added technical unreliability to scientific uncertainty as reasons for dismissing the ACCV's tar test as useful consumer information. However, the Australian manufacturers were yield testing for quality assurance purposes and regularly made cross-laboratory comparisons. ${ }^{22}{ }^{23}$ This practice would scarcely make sense if the manufacturers believed yield testing was inherently unreliable. Furthermore, the editorial made no mention of the US FTC's programme to standardise yield testing, then nearing completion. ${ }^{4}$

Also noteworthy in this editorial was a prediction about future tobacco industry conduct and another reference to the "potentially increased harm" argument to warn the government against becoming involved in a low tar programme:

[l]t is unlikely that Australian manufacturers will embark on a "Tar Derby" by proclaiming the lower nicotine and tar content of their own brands against others. The Government will also need to be cautious of agitation to force manufacturers to show nicotine and tar content on packages as this might prove to have an effect opposite to what the agitators desire by giving smokers a sense of security they do not have at present. ${ }^{21}$

The industry was also at work behind the scenes attempting to block the low tar programme. Soon after the first ACCV tar test, the federal Health Minister, AJ Forbes, and the Victorian Health Commission referred the issue of tar and nicotine in Australian cigarettes to the National Health and Medical Research Council (NHMRC) (which controls government funding of medical research and provides independent advice on policy matters). The manufacturers responded with a collective submission to the NHMRC, urging it to consider the evidence carefully before making any recommendations. ${ }^{24}$ The submission argued that scientific uncertainty about whether smoking causes disease and the technical unreliability of tar testing rendered the proposed low tar programme useless. However, the submission was not purely contrarian. It identified three areas deserving "original Australian scientific research .... [to resolve the] smoking and health question":

(1) fractionalisation studies of the components of tar

(2) studies of the biological activity of whole smoke

(3) studies of the "effects on the human body of other environmental sources, such as air pollution, pesticide residues on food, etc." 24

The submission continued:

\section{The Tobacco manufacturers are so convinced of the need for original Australian scientific research of this nature that they are prepared to shoulder the considerable financial burden involved and ready to make highly qualified scientific staff and extensive facilities available. ${ }^{24}$}

This particular effort to gain good will failed but the industry still had a victory of sorts. The NHMRC recommended to the 1967 health ministers' conference that cigarette packets should carry a warning on danger to health and a statement of tar content. ${ }^{8}$ The ministers deferred the matter, apart from issuing a statement that responsibility for the production of safer cigarettes rested with the manufacturers. ${ }^{25}$ In 1969 federal legislation enabled health warnings and in 1973 this was implemented, with one message ("Warning - Smoking is a health hazard") printed on packs. ${ }^{26}$ On-pack labelling of tar and nicotine yields was not implemented until 1982. ${ }^{26}$
The NHMRC also declined to collaborate with the tobacco industry in the proposed research programme. However, the British Tobacco Company (Aust) (BTCA) (later Wills and now BATA, since the merger of Wills and Rothmans in 1998) was already at work behind closed doors researching the components of tar and the biological activity of whole smoke. ${ }^{27}$ BTCA later conducted other research of interest to health authorities but again kept it secret. Tasman Wilson, head of tobacco smoke research for BTCA, led research on tar and nicotine absorption and "human-cigarette interactions", contributing to an understanding that compensation would seriously undermine the low tar programme..$^{23}{ }^{28-30}$ As early as 1967, Wilson took the position that compensation negated the anticipated utility of tar yields as a guide to smokers' intakes. In a study of the effect of smoke concentration on human smoking characteristics, he concluded:

The experiment has demonstrated the fact that humans have an inbuilt compensation mechanism.... TPM figures produced from a smoking machine are not a fair representation, even relatively, of the amount of smoke a human will obtain from a given cigarette. ${ }^{28}$

While the claim that there is little relation between tar and nicotine yields and actual intakes was later made public in a tobacco industry submission to the Senate Standing Committee on Social Welfare in 1976, no supporting evidence was given. In the absence of any real attempt to persuade a sceptical audience, this claim was lost among the mass of claims in the industry's submission that the Senate Committee dismissed as self contradictory and misleading. ${ }^{31} 32$

\section{The low tar programme consolidates}

Following the retirement of EV Keogh in March 1968, the incoming director, Nigel Gray, re-committed the ACCV to the low tar programme. In collaboration with the department of chemistry at Monash University and later the University of Waterloo, Canada, the ACCV published a further seven tar tables between 1968 and 1974. The publication of each new tar table was a significant event in the campaign, with the media giving generous coverage on each occasion.

The ACCV's second tar table in 1968 showed that a reformulated brand, Hallmark Dual Filter (Myria Filter), and a new brand, Ransom, had tar yields of $7.1 \mathrm{mg}$ and $7.4 \mathrm{mg}$ respectively, rivalling the lowest yielding US brands. ${ }^{25}$

Appearing at the top of the ACCV's tar tables appeared beneficial for sales. By 1972, Hallmark became the sixth highest seller in Victoria (among 97 brands), with $4 \%$ of market share. ${ }^{9}$ Hallmark also held a $1.5 \%$ market share nationally in 1974, up from $0.08 \%$ when the second ACCV tar table was published. ${ }^{12}{ }^{33}$ Further, the number of available low tar brands (defined by the ACCV as $<12 \mathrm{mg}$ tar yield) rose from two in 1969 to 11 in 1974 (table 1). ${ }^{34}$ While the total number of low tar smokers remained modest in this period, the industry evidently had adequate incentive to develop new low tar brands.

In 1974, the federal Department of Health began a comprehensive testing programme, with the tests conducted by the Australian Government Analytical Laboratories (AGAL). Whereas the ACCV only had sufficient resources to test selected local brands, the tar and nicotine yields of all locally manufactured brands, as well as the more popular imported ones, would henceforth be available.

Despite the "official" nature of the Department of Health tar tables, the end of the ACCV's direct role in tar testing evidently came as a relief to the tobacco industry. A 1984 BAT UK document on "league tables" (that is, tar tables) drew the following lesson from the Australian experience: 
Table 1 Percentage of tested locally manufactured brands in each tar yield category 1968-1991. Data from ACCV tar tables 1968-75 and Commonwealth Department of Health smoke yield tables 1977-91

\begin{tabular}{|c|c|c|c|c|c|c|c|c|}
\hline & \multicolumn{7}{|c|}{ Tar yield (mg) } & \multirow{2}{*}{$\begin{array}{l}\text { Number of } \\
\text { brands tested }\end{array}$} \\
\hline & 1 & 2 & $3-4$ & $5-8$ & $9-12$ & $13-16$ & $>16$ & \\
\hline 1968 & - & - & - & 8 & - & 12 & 80 & 25 \\
\hline 1969 & - & - & - & 6 & - & 9 & 85 & 34 \\
\hline 1971 & - & - & - & 5 & 4 & 46 & 45 & 55 \\
\hline 1972 & - & - & - & 6 & 13 & 57 & 24 & 53 \\
\hline 1974 & - & - & - & 7 & 11 & 51 & 31 & 61 \\
\hline 1975 & - & - & - & 13 & 29 & 47 & 11 & 31 \\
\hline 1977 & - & - & - & 5 & 19 & 51 & 25 & 85 \\
\hline 1978 & - & - & - & 4 & 21 & 50 & 25 & 96 \\
\hline 1980 & 1 & 1 & - & 11 & 23 & 48 & 16 & 103 \\
\hline 1984 & 1 & - & 2 & 10 & 50 & 37 & - & 133 \\
\hline 1986 & 1 & 1 & 2 & 26 & 59 & 11 & - & 129 \\
\hline 1988 & 1 & 3 & 7 & 27 & 53 & 9 & - & 159 \\
\hline 1991 & 1 & 6 & 17 & 27 & 44 & 5 & - & 150 \\
\hline
\end{tabular}

An "unofficial" league table poses a considerable threat to cigarette manufacturers because of the unknown factors involved: which and how many brands are included; how are the tests conducted; what ranking system is used; and the nature of the commentary, for example. ${ }^{12}$

In other words, "official" tar tables made for greater predictability. Governments and bureaucrats might also be expected to treat the tobacco industry as a suitable party for negotiation over future development of the system, rather than treating it purely as an opponent.

Negotiations between the tobacco industry and the government were the basis for the implementation of the final element of the ACCV's low tar programme, when the first of several voluntary agreements on pack labelling of yields was enacted in $1982 .{ }^{26}$ This agreement was negotiated following recommendations by the Senate in 1977 that tar and nicotine contents be labelled on packs and maximum permissible levels set. ${ }^{32}$ It stipulated maximum tar yields of $16 \mathrm{mg}$ and nicotine yields of $1.6 \mathrm{mg}$ (after an initial one year period, when tar yields of up to $18 \mathrm{mg}$ were permitted) as well as on pack labelling of nominal tar and nicotine yields in four tar yield "bands", ranging from $4 \mathrm{mg}$ tar, $0.4 \mathrm{mg}$ nicotine to $16 \mathrm{mg}$ tar, $1.6 \mathrm{mg}$ nicotine. The industry had sought permissible tar yields of up to $24 \mathrm{mg}$ but did not prevail. $^{35}$

After the first voluntary agreement on labelling, the ACCV assumed it had taken the low tar programme as far as possible and concentrated its limited resources on reducing uptake and increasing cessation, with further advertising restrictions and tax increases as its immediate objectives. However, the end of the ACCV's system building efforts did not mean the end of developments in communication of yield information. Subsequent voluntary agreements between the Department of Health and the tobacco manufacturers resulted in the inclusion of carbon monoxide yields on pack labels in 1989, as well as the addition of $2 \mathrm{mg}$ or less and $1 \mathrm{mg}$ or less tar bands in 1989 and $1990 .{ }^{26}$ Most recently, in 1997, the $8 \mathrm{mg}$ band became differentiated, with the emergence of $6 \mathrm{mg}$ or less brands. ${ }^{36}$

Available records do not reveal whether the Department of Health or the tobacco industry proposed any of the additional yield bands. A PML document ${ }^{37}$ shows that the tobacco industry prevailed over the government, which sought an upper limit of $12 \mathrm{mg}$ for tar yields while negotiating the second voluntary agreement. Phil Francis of PML observed that: "to finish up with a limit of $16 \mathrm{mg}$ was somewhat of a bonus." ${ }^{\prime 37}$ The industry may also have received a bonus by being able to use the "6 mg or less" tar band since 1997, as the Commonwealth Trade Practices regulations on the labelling of tobacco products do not to include it. ${ }^{38}$ The maintenance of the "16 mg or less" band and the introduction of $1 \mathrm{mg}, 2 \mathrm{mg}$, and $6 \mathrm{mg}$ bands have all served the tobacco industry's interest of maximising the "illusion of control"39 for consumers.

\section{"Lights" and "milds" enter the market}

While Hallmark and Ransom seemed to have been introduced in direct response to the ACCV's campaign, the tobacco industry had a different story to tell. BTCA claimed it developed Hallmark to meet the demands of smokers seeking a different taste and made no claims it was "safer". ${ }^{40}$

The "different taste" of brands like Hallmark was frequently identified as "mild" or "light". However, these terms do not only indicate reduction in taste strength. Whatever disclaimers the industry has made, they also strongly suggest reduction in harmfulness. ${ }^{31}$

In 1971, the first "mild" line extension, Craven A Special Mild, was introduced. Smokers consulting the 1971 tar table would find that Craven A Special Mild had a tar yield of $9 \mathrm{mg}$, compared to $16 \mathrm{mg}$ for Craven A.

"Light" and "mild" line extensions of leading brands began to proliferate in 1974, with the descriptors always indicating lower tar and nicotine yields within particular brand lines. In 1979, the process was taken a step further, when the first "ultra mild" lines were introduced. By 1990, when Australian brands were differentiated into six "bands" of nominal tar yields, many major brand families extended to six lines, running through various "extra", "super", and "ultra" / "light" and "mild" descriptors to "ultimate" or " 1 " lines.

Well before $1 \mathrm{mg}$ tar yield brands appeared, the contradictions involved in representing increasingly bland flavour as the drawcard of the lowest yielding brands sharpened. It eventually became necessary to explicitly claim high satisfaction at the yield level, acknowledging that smokers care about tar yields, rather than just "mild" flavour. For instance, promotions for PML's Belmont centred on favourable yield/ satisfaction ratios:

A new $2 \mathrm{mg}$ that satisfies like a $4 \mathrm{mg}$

A $4 \mathrm{mg}$ that satisfies like an $8 \mathrm{mg}$

An $8 \mathrm{mg}$ that satisfies like a $12 \mathrm{mg}$ 
Because only Belmont's unique twin density filter with its dense inner core gives you satisfaction at a lower tar level.

\section{At last you can lower your tar not your satisfaction. ${ }^{42}$}

PML's launch plan for Belmont noted:

The target market are concerned with the health issues and social pressures surrounding the category [of low tar cigarettes]. Whilst they believe that smoking a lower delivery cigarette would alleviate...these pressures...they have either tried [and rejected] a milder cigarette or perceive [a] barrier [to satisfaction]. ${ }^{43}$

Some of the steps taken by the manufacturers to remove barriers to satisfaction will be dealt with in the next section.

\section{Re-engineering low tar cigarettes for "satisfaction"} As has been noted, in the late 1960s and early 1970s, only a modest proportion of Australian smokers found low tar brands acceptable, but there has been spectacular growth in the market share of low tar brands since then. ${ }^{44}$ The industry has claimed bragging rights over this and has received congratulation from governments. ${ }^{45} 46$ However, the growth of low tar brands did not necessarily mean more smokers adjusted to lower intakes of tar and nicotine. A more plausible explanation is that:

(1) early successful down-switchers already had low nicotine intakes and had little difficulty maintaining them with low tar brands, whereas unsuccessful down-switchers had higher nicotine intakes and were unable to maintain them

(2) in more recent years, low tar cigarettes have been reengineered to facilitate compensation, enabling smokers with higher nicotine intakes to down-switch with relative ease and enabling smokers with lower nicotine intakes to switch to brands with very low yields. ${ }^{47}$

The available evidence is consistent with the first low tar cigarettes in Australia having been relatively unconducive to compensatory smoking. For example, Hallmark had low nicotine content tobacco and heavy filters, producing high draw resistance and discouraging large puffs. ${ }^{47}$ Also, consumers frequently reported that Hallmark and Ransom were both excessively difficult to draw on and unsatisfying. ${ }^{1}$

The Australian industry's first attempt to facilitate compensation appears to have been the use of alkaline filter additives to boost pharmacologically effective nicotine deliveries. Tasman Wilson's research included several studies on the effects of alkaline additives on "extractable" nicotine in cigarette smoke ${ }^{48}{ }^{49}$ (a measure of levels of unprotonated or "free" nicotine, which is much more rapidly absorbed than the protonated or "bound" form). In 1971, Wilson concluded that the addition of sodium carbonate to filters would be "advantageous for mild, low nicotine, low TPM cigarettes". ${ }^{50}$ Subsequently, an additive codenamed GORLIND was employed in Hallmark. ${ }^{49}$

A more radical change to Australian low tar cigarettes was the introduction of filter ventilation around $1974 .^{5152}$ Filter ventilation is the most important technology enabling the current range of FTC/ISO yields in Australian cigarettes. ${ }^{47}$ However, while an effective means of reducing yields, it is not an effective means of restricting intakes. Smokers frequently block vents with their fingers and lips to increase smoke concentration and, at lower levels of ventilation, can negate yield reductions simply by taking larger and more frequent puffs. ${ }^{53}$
The utility of filter ventilation for reducing yields, while facilitating compensation, was well understood within the Australian industry when it was introduced. Tony Foster, research and development manager of PML, made these revealing comments on the merits of super porous tipping (subsequently employed in Kent Golden Lights):

The first [point of interest is that] the consumer will not have his attention drawn to the fact that the tipping is indeed, perforated; secondly, if he becomes used to smoking super porous tipping products, his technique may come to accommodate the super porous effect, so that his smoke dosage is tailored for his personal need. ${ }^{54}$

PML began test marketing brands with filter ventilation in $1975 .^{55}$ By the end of the 1970s, all three manufacturers were marketing ventilated brands, ${ }^{56}$ although none were ever identified as such in advertising. By the early 1990s, around $90 \%$ of Australian brands had filter ventilation. ${ }^{44} 57$

Another step in the re-engineering process for low tar brands made possible by filter ventilation was increased nicotine content. In 1980 most low tar brands in Australia used low nicotine tobacco $(<2 \%$ alkaloids, dry weight basis $)$, but in 1994 all $1 \mathrm{mg}$ and $2 \mathrm{mg}$ brands used high nicotine tobacco $(2.3 \%$ or higher $)$, as did the majority of $4 \mathrm{mg}$ brands. ${ }^{47}$

With the possible exception of the AGAL, no organisation in Australia outside the tobacco industry was aware of the existence of filter ventilation in the 1970s, let alone its role in compensatory smoking. At the time filter ventilation was introduced, the ACCV accepted that new low tar brands would enable smokers to reduce tar and nicotine intakes further. A 1975 article in Victorian Cancer News, noting that Ransom had been substantially remodelled, welcomed the change and saw it as a sign of things to come:

[I]t seems likely that the cigarette of the future will be low in both tar and nicotine and will have a reduced carbon monoxide yield as well. The Council advises smokers who are unable to give up the habit to smoke the lowest tar cigarette which is acceptable to them. ${ }^{58}$

A number of tobacco control advocates in Australia later became aware of filter ventilation, as a result of such sources as the 1981 US Surgeon General's report. ${ }^{59}$ Gray, in particular, became increasingly concerned about the extent to which compensatory smoking was undermining the low tar programme. $^{60}$ Nonetheless, until the 1990s, there was a consensus that low tar smokers had reduced intakes, even if the reductions were considerably less than originally hoped for.

\section{Revealing the low tar deception}

Evidence that the Australian tobacco industry was subverting the low tar programme by re-engineering cigarettes first emerged in the 1980s, partly as a result of a public breakdown in cooperation within the industry. The precipitating event was the introduction of Barclay, controversial internationally for "99\% tar-free" promotions and its channel ventilated design. ${ }^{61} 62$

Wills test launched Barclay in Brisbane in 1982 (where it remains on sale) but competitors ensured it was not marketed elsewhere. Andrew Whist, of PML, reported that when Barclay was launched:

PM "went the jugular" and told the BAT company [Wills] that should they expand the launch they [PM] would go 
public on the whole cheating issue with the press and authorities, thereby calling into question not only this but also their other brands. ${ }^{63}$

Despite Wills' assurance that there would be no nationwide launch of Barclay, competitors lodged an official objection to its yields being determined by the standard FTC/ISO test. ${ }^{63}{ }^{64}$ The Department of Health did not uphold this objection and it does not appear that broader questions about the validity of yield testing arose. ${ }^{64}$ According to a Brown and Williamson document, AGAL and the Department of Health wanted to avoid any change to testing procedures and also wanted to avoid public controversy. ${ }^{65}$

Barclay later became subject to critical public attention. A 1985 article in Choice on manipulation of the yield testing system reported research by Lynn Kozlowski and colleagues showing that Barclay's ventilation channels are easily crushed and its tipping perforations covered by smokers' fingers or lips. However, the article did not raise the possibility that all ventilated filter cigarettes manipulated the yield testing system in much the same way. Further, while noting research suggesting compensation was complete in most cases, the author/s argued: "until more is known, we should not see this as sufficient evidence to switch from lowtar cigarettes." Arguably, for the tobacco control community as well as the Department of Health, a valuable opportunity to reassess the low tar programme was missed.

A stronger warning that low tar cigarettes are unlikely to provide real relative health benefits came in 1993. In the lead up to the AGAL cigarette testing laboratory being closed down in 1994 and the manufacturers conducting all yield testing, the head of its cigarette research unit, Gary Evans, went public with a study of the effects of ventilation blockage and increased puff count. ${ }^{57}$ A consumer affairs TV programme, A Current Affair, put the issue of the low tar deception before a very large audience, although the sensational treatment may not have facilitated a clear understanding of it. ${ }^{66}$ An article in Choice took a more measured approach, explaining in detail how ventilated filter cigarettes facilitate compensation and presenting the AGAL results demonstrating the effects of vent blockage and increased puff count on the yields of the most popular Australian brands. ${ }^{67}$ For several $1 \mathrm{mg}$ brands, tar yields increased to over $8 \mathrm{mg}$ with ventilation fully blocked and doubling of puff frequency generally led to more than doubling of yields. The importance of this message was possibly undercut by suggestions that low tar smokers could consciously avoid compensating. Nonetheless, there was now well disseminated, convincing evidence that all Australian low tar cigarettes had been re-engineered to facilitate compensation. As further evidence emerged that real tar and nicotine intakes bear little relation to FTC/ISO yields, ${ }^{68} 69$ the Australian tobacco control community moved toward the position that the low tar programme is an obstacle to harm minimisation and should be dismantled. ${ }^{2} 70$

\section{Industry defences of the low tar programme}

As public awareness of filter ventilation and compensatory smoking increased, the tobacco industry moved toward explicit claims that low tar cigarettes enable smokers to reduce their intakes and that counter-evidence is either exaggerated or only applies to a minority of smokers. Philip Morris' 1993 "Key Message Book for Representatives" claimed:

Low tar cigarettes are designed with normal smoking behaviour in mind, and although smokers may cover some of the ventilation holes, they do so rarely. Under normal circumstances, the way a smoker holds a low tar cigarette should not change the smoke yield ... ${ }^{71}$

This could be an effective reassurance for some smokers who are aware of either general messages that low tar cigarettes do not work or specific messages that filter ventilation is designed to cheat the testing process. Low tar smokers' sensory experiences of weaker taste and reduced irritation lead many to believe they are reducing their risks individually, even if other low tar smokers are not. ${ }^{72}$

Ten years on the industry is continuing to defend low tar cigarettes. The BATA website currently expresses confidence that low tar cigarettes are effective in practice:

The key reason that some are currently questioning the possible reduction in risk from low tar cigarettes is a phenomenon called 'compensation.' .... In our opinion, current scientific information suggests that compensation is not so pronounced once smokers become accustomed to a new product, and that, in general, smokers of lower tar products take less tar than higher tar smokers. ${ }^{74}$

However, the website also suggests that smokers should avoid taking more and deeper puffs. ${ }^{75}$ This advice implicitly makes smokers responsible for failing to avoid compensating.

Low tar smokers have not been the industry's only targets for persuasion over the past decade. The industry has again been working hard to persuade governments that inaction is the prudent option-but this time around inaction means the low tar system stays in place.

In 1995 a Senate Community Affairs References Committee report made 39 recommendations for government regulation of the tobacco industry, including:

That the current testing procedures for cigarette yields be reviewed by an appropriate independent body to determine whether these procedures accurately reflect the actual levels of tar, carbon monoxide and nicotine inhaled by smokers.... ${ }^{76}$

PML produced a point-by-point response to the report, including a defence of the FTC/ISO yield test. ${ }^{77}$ According to PML:

The purpose of the ISO method is not to mimic human smoking but to provide a uniform basis for comparison of TCN yields across a broad range of cigarette brands. The TCN yields produced by the ISO methodology are a guide to smokers in the same way that 'litres per $100 \mathrm{kms}$ ' ratings are a guide to car purchasers... [N]ot everyone who drives a 4 cylinder car will get the same fuel efficiency. Similarly, not every smoker of a cigarette with ... $4 \mathrm{mg}$ 'tar' will actually get that delivery. ${ }^{.7}$

This is a textbook example of fallacious argument. The studied avoidance of the whole issue of compensatory smoking is also quite remarkable. However, a technically poor argument can be strong for practical purposes and PML vice-president for corporate affairs, Donna Staunton, repeated it in 1998 after federal Minister for Health, Michael Wooldridge, requested information on the constituents, additives, and manufacturing processes of Australian cigarettes. ${ }^{78} 79$ Staunton also furnished the minister with the following sketch of the evolution of the Australian cigarette:

Australia has a greater proportion of sales that fall in a lower 'tar' category than many other countries. Much of 
our manufacturing technology has been directed towards developing acceptable tasting cigarettes in the low 'tar' market sector. ${ }^{79}$

However, the minister was apparently not furnished with information about changes in filters, filter ventilation, nicotine contents, and additives that led to the "acceptable tasting" low tar cigarettes which now dominate the Australian market.

Wooldridge's attempt to "ensure an unprecedented level of tobacco product disclosure in Australia" ${ }^{\prime 80}$ culminated in the most recent voluntary agreement between the federal Department of Health and the Australian tobacco industry. Drafts of the agreement show it was originally intended to deal with the disclosure of additives and emissions of Australian cigarettes. ${ }^{81}$ However, the agreement signed in December 2000 was entitled "Voluntary agreement for the disclosure of the ingredients of cigarettes" and contained only a single paragraph flagging possible future extension to include emissions disclosures. ${ }^{82}$

Industry documents reveal substantial resistance to emissions disclosures. ${ }^{83}{ }^{84}$ However, following the 2000 voluntary agreement, the industry made a once-off disclosure of the mainstream and sidestream emissions of 38 carcinogens and other toxins for 15 top selling brands, using both FTC/ISO and Canadian intensive smoking parameters (that is, $55 \mathrm{ml}$ puff, every 30 seconds with ventilation fully blocked). This was quietly posted on the Department of Health website. ${ }^{85}$ However, at the time of writing, packs continue to carry FTC/ ISO yield figures and the industry continues to use "light" and "mild" descriptors, as well as incorporating tar yields in some brand names. In short, the efforts to reassess the low tar programme have not so far led to decisive action to end the low tar deception.

\section{CONCLUSION}

At the time of writing, the BATA website ${ }^{86}$ informs readers interested in "safer" cigarettes:

\section{The main modifications which have proved acceptable to consumers, governments and health authorities have been lower tar cigarettes. Our research, in addition to looking at ways to reduce the tar, has included investigating how specific constituents of smoke might be selectively reduced.... [Research] currently focuses on continued development of very low tar cigarettes acceptable to consumers, lower tar cigarettes with certain smoke constituents reduced further, and novel designs that significantly change the composition of the smoke.}

This quote is scarcely consistent with the tobacco industry facing up to its past actions. There is a failure to acknowledge that acceptance of low tar cigarettes by both health authorities and the general public stemmed in large part from industry efforts to mislead them. There is no good reason to believe that BATA or its competitors can be trusted to act differently in future.

Given the evident failure of past voluntary agreements in Australia to control industry conduct and the ongoing inability of the industry to fully acknowledge that low tar cigarettes do not work, there is no viable alternative to the Australian government acting decisively to dismantle the low tar programme. The most important measures to take are:

(1) removal of FTC/ISO yield figures from cigarette packs

(2) banning of misleading light and mild descriptors

(3) investigation of a ban on the use of filter ventilation.
What this paper adds

It is widely agreed that low tar harm reduction programmes have been a failure internationally. However, the causes of this failure in the Australian context have not been systematically documented, apart from some research on the changing construction of Australian cigarettes.

This paper draws on industry documents to reveal details of the tobacco industry's attempts to block the Australian low tar programme and, later, subvert it, while appearing compliant. The paper also documents the path by which the Australian tobacco control community came to learn that the low tar programme has failed and must be treated as an obstacle to the objective of minimising the smoking attributable disease burden.

There should also be a large scale public education campaign giving a detailed explanation of why these changes are being made and the implications for smokers. We suggest that these measures are also required in many other countries where low tar cigarettes currently provide the principal means of "health reassurance".

As the above quote also indicates, a new generation of tobacco products with harm reduction claims are under development by the tobacco industry and, in some overseas markets, novel tobacco products with harm reduction claims are already available. It is plausible that some new generation tobacco products could play a role in a successor harm reduction programme. However, where sale of such products is to be permitted, they must be subject to stringent regulation of emissions and rigorous monitoring of consumers' exposures. If the tobacco control community and governments simply hope for the best with new generation tobacco products, we could be setting up yet another large scale public health experiment for failure.

\section{ACKNOWLEDGEMENTS}

The research reported in this paper was supported by grants from the National Health and Medical Research Council (2001-2003 \#153857) and the US National Institutes of Health (2001-2005 \# R01 CA87110-01Al). Fiona Byrne, information manager for the Australian and Asian tobacco documents project, helped with document searching. David Hill, Jane Martin, and Stephen Woodward offered insider perspectives on historical developments.

\section{Authors' affiliations}

W King, R Borland, VicHealth Centre for Tobacco Control, The Cancer Council Victoria, Victoria, Australia

S M Carter, S Chapman*, School of Public Health, University of Sydney, Sydney, New South Wales, Australia

N Gray, European Institute of Oncology, Milan, Italy

*Also Associate Director, VicHealth Centre for Tobacco Control

\section{REFERENCES}

1 Brian Sweeney \& Associates (Aust) Pty Ltd. A first phase research report on new product \& concept ideas prepared for Philip Morris Ltd. May 1983. Philip Morris. Bates No. 2043884195/4231. http://legacy.library.ucsf.edu/tid/ $\operatorname{tg} 06 \mathrm{e} 00$

2 Gray N. Reflections on the saga of tar content: why did we measure the wrong thing? Tobacco Control 2000;9:90-4.

3 Pollay R, Dewhirst T. Marketing cigarettes with low machine-measured yields. In: The FTC cigarette test method for determining tar, nicotine and carbon monoxide yields of US cigarettes. Bethesda, Maryland: US Dept of Health and Human Services, Public Health Service, National Institutes of Health, National Cancer Institute, 1996:199-235. (Smoking and tobacco control monographs no. 7; NIH publication no. 96-4028).

4 Peeler C. Cigarette testing and the Federal Trade Commission: a historical overview. In: The FTC cigarette test method for determining tar, nicotine and carbon monoxide yields of US cigarettes. Bethesda, Maryland: US Dept of Health and Human Services, Public Health Service, National Institutes of 
Health, National Cancer Institute, 1996:1-8, (Smoking and tobacco control monographs no. 7; NIH publication no. 96-4028).

5 Bijker WE, Hughes TP, Pinch TJ, eds. The social construction of technological systems: new directions in the sociology and history of technology. Cambridge, Massachusetts: MIT Press, 1989.

6 Bijker WE, Law J, eds. Shaping technology/building society: studies in sociotechnical change. Cambridge, Massachusetts: MIT Press, 1992.

7 Bradford J, Harlan W, Hanmer H. Industrial and Engineering Chemistry. Nature of cigaret smoke: technic of experimental smoking [sic]. Jul 1936. American Tobacco Company. Bates No. 950245003/5007. hitp:// legacy.library.ucsf.edu/tid/ghf34f00

8 Anti-Cancer Council of Victoria. Risks in Australian cigarettes. Victorian Cancer News 1967;(No. 34): 1-2.

9 Tyrrell I. Deadly enemies: tobacco and its opponents in Australia. Sydney: UNSW Press, 1999.

10 Australian-made cigarettes: a preliminary report. Choice 1961;2(no. 2):36-43.

11 Australian-made cigarettes: a further report. Choice 1961;2(no. 2):68-72.

12 Heath A. The impact of league tables. Apr 1984. Brown \& Williamson. Bates No. 690120538/0615. http://legacy.library.ucsf.edu/tid/prr13f00

13 Anti-Cancer Council of Victoria. Rogues in filtered clothing. Victorian Cancer News 1966;(No. 29): 1.

14 Anon. "Nicotine and tar". Tobacco Journal 1967 Feb:5.

15 Anon. What 'Readers Digest' didn't say. Tobacco Journal 1967 Feb:6.

16 Benowitz N. Compensatory smoking of low yield cigarettes. In: Risks associated with smoking cigarettes with low machine-measured yields of tar and nicotine. Bethesda, Maryland: US Dept of Health and Human Services, Public Health Service, National Institutes of Health, National Cancer Institute, 2001:39-63, (Smoking and tobacco control monographs no. 13; NIH publication no. 02-5047).

17 Gray N, Kozlowski LT. More on the regulation of tobacco smoke: how we got here and where next. Ann Oncol 2003;14:353-7.

18 Hoffmann D, Djordjevic MV, Hoffmann I. The changing cigarette. Prev Med 1997:26:427-34.

19 Grant M. Here's a filter that tames the killer tar. The Herald (Melbourne, Vic) 5 May 1968:6-7.

20 Anti-Cancer Council of Victoria. New smokers' tar table released. Victorian Cancer News 1974:(No. 70):3.

21 Anon. No "Tar Derby". Tobacco Journal 1967 Oct:3.

22 Philip Morris Incorporated Research and Development Department Australian test \#150, MR4-06AA: Smoke profile of Australian Marlboro. 16 Feb 1966. Philip Morris. Bates No. 1000830255/0257. http:// legacy.library.ucsf.edu/tid/ksr54e00

23 British Tobacco Company (Australia) Limited Central Laboratories Research Department. Quarterly report, November 1968-January 1969. Feb 1969. Brown \& Williamson. Bates No. 650338201/8221. http:// legacy.library.ucsf.edu/tid/zkloofo0

24 Philip Morris (Australia) Limited. [Letter to W. Refshauge, Chairman, National Health and Medical Research Council]. 19 Oct 1967. Philip Morris. Bates No. 2025036921/6925. http://legacy.library.ucsf.edu/tid/qeq25e00

25 Anti-Cancer Council of Victoria. Tar yields in Australian cigarettes: new list. Victorian Cancer News 1968;(No. 40):1-2.

26 Winstanley M, Woodward S, Walker N. Tobacco in Australia: facts and issues. Melbourne: Victorian Smoking and Health Program, 1995.

27 British Tobacco Company (Australia) Limited Central Laboratories Research Department. Bimonthly report no. 23. Jul-Aug 1965. Brown \& Williamson. Bates No. 650333901/3924. http://legacy.library.ucsf.edu/tid/orl00f00

28 Wilson T. Effect of cigarette smoke concentration on human smoking characteristics. Oct 1967. British American Tobacco. Bates No. 402361933/ 1945. http://www.library.ucs.edu/tobacco/batco/html/10200/10276 (Accessed 10 Jun 2003).

29 British Tobacco Company (Australia) Limited Central Laboratories Research Department. Bimonthly report no. 27. Mar-Apr 1966. Brown \& Williamson. Bates No. 650334883/4901. http://legacy.library.ucsf.edu/tid/vsl00f00

30 British Tobacco Company (Australia) Limited Research \& Development Department. Quarterly report, February 1969-April 1969. May 1969. Brown \& Williamson. Bates No. 650338222/8240. http://legacy.library.ucsf.edu/ $\mathrm{rid} / \mathrm{all} 00 \mathrm{fOO}$

31 Australian Cigarette Manufacturers. "Tar" and nicotine [Addendum no. 5 to the Australian Cigarette Manufacturers submission to the Senate Standing Committee on Social Welfare]. 19 Apr 1977. R.J. Reynolds. Bates No. 504845062/5069. http://legacy.library.ucsf.edu/tid/wsi55d00

32 Senate Standing Committee on Social Welfare. Drug problems in Australiaan intoxicated society?: report. Canberra: AGPS, 1977. (AGPS Cat. no. 7728912)

33 Philip Morris (Australia) Limited. [CPM of top brands: tables forming part of a presentation to H. Maxwell]. 19 Feb 1975. Philip Morris. Bates No. 2024258855/8856. http://legacy.library.ucsf.edu/tid/zrx24e00

34 Anti-Cancer Council of Victoria. The smoking situation - 1976 [Submission to Senate Standing Committee on Social Welfarel. Melbourne: ACCV, 1976.

35 Australian Cigarette Industry. Aide memoire "Content labelling on cigarette packets". 11 Mar 1981. Philip Morris. Bates No. 2023084937/4943. http://legacy.library.ucsf.edu/tid/ibn68e00

36 Australian Retail Tobacconist. Benson \& Hedges Lights 6: a first in Australia. Australian Retail Tobacconist 1997 Oct:8.

37 Francis P. Maximum constituency levels. 27 Nov 1987. Philip Morris. Bates No. 2025822121. http://legacy.library.ucsf.edu/tid/maq95e00

38 Trade Practices (Consumer Product Information Standards) (Tobacco) Regulations-Schedule 3 1994. http://www.austlii.edu.au/au/legis/cth/ consol_reg/tppisr714/ (Accessed 23 Sep 2003).
39 Hansen J, Kysar D. The joint failure of economic theory and legal regulation. In: Slovic P, ed. Smoking: risk, perception and policy. Thousand Oaks, California: Sage, 2001:229-76.

40 Daily Telegraph. Council row on smoking report. 1968. Philip Morris. Bates No. 1002403136. http://legacy.library.ucsf.edu/tid/tzx67e00

41 Weinstein N. Public understanding of risk and reasons for smoking low-yield products. In: The FTC cigarette test method for determining tar, nicotine and carbon monoxide yields of US cigarettes. Bethesda, Maryland: US Dept of Health and Human Services, Public Health Service, National Institutes of Health, National Cancer Institute, 1996:193-98, (Smoking and tobacco control monographs no. 7; NIH publication no. 96-4028).

42 Philip Morris. Belmont [advertisement]. Australian Retail Tobacconist 1990 Nov: 10

43 Philip Morris (Australia) Limited. Project Dagger launch plan. $26 \mathrm{Jul} 1990$ Philip Morris. Bates No. 2504077083/7094. http://legacy.library.ucsf.edu/ $\mathrm{tid} / \mathrm{qpi} 29 \mathrm{e} 00$

44 Ruff R. Philip Morris Limited (Australia) C.I. report no. 84. Jun 1994. Philip Morris. Bates No. 2057967669/7753. http://legacy.library.ucsf.edu/tid/ vcp96e00

45 Tobacco labelling. 7 Sep 1990. Philip Morris. Bates No. 2021551 100/1103. http://legacy.library.ucsf.edu/tid/wje58e00

46 Australian Cigarette Industry. [Draft proposal for Joint Government-Industry Program to develop safer cigareftes]. 1 Jan 1972. Philip Morris. Bates No. 1000211242/1248. http://tobaccodocuments.org/bliley_pm/20664.html (Accessed 10 Jun 2003)

47 King W, Borland R. The "low tar" programme and the changing construction of Australian cigarettes. Nicotine Tob Res, (in press)

48 Wilson T. British Tobacco Company (Australia) Limited. The alteration of extractable nicotine level in smoke by filter additives. Feb 1971. Brown \& Williamson. Bates No. 650361989/2001. http://legacy.library.ucsf.edu/ $\mathrm{tid} / \mathrm{eik} 0 \mathrm{OfOO}$

49 Wilson T. British Tobacco Company (Australia) Limited. Hallmark-impact studies (Report no. T.56). Jan 1973. Brown \& Williamson. Bates No. 650366317/6341. http://legacy.library.ucsf.edu/tid/nbk00fo0

50 Wilson T. British Tobacco Company (Australia) Limited. Comparison of filters made from cellulose acetate, myria and myria with added sodium carbonate. Mar 1971. Brown \& Williamson. Bates No. 650362002/2017. http:// legacy.library.ucsf.edu/tid/fik00foO

51 Haslam F. Cigarettes with ventilated filters. 24 Aug 1977. British American Tobacco. Bates No. 100443599. http://www.library.ucsf.edu/tobacco/ batco $/ \mathrm{html} / 2600 / 2652 /$ (Accessed 27 Sep 2001).

52 Haslam F. [Attachment to memo from F. Haslam re: Cigarettes with ventilated filters] 24 Aug 1977. British American Tobacco. Bates No. 100443600 http://www.library.ucsf.edu/tobacco/batco/html/2600/2653/ (Accessed 27 Sep 2001).

53 Kozlowski L, O'Connor RJ, Sweeney CT. Cigarefte design. In: Risks associated with smoking cigarettes with low machine-measured yields of tar and nicotine. Bethesda, Maryland: US Dept of Health and Human Services, Public Health Service, National Institutes of Health, National Cancer Institute, 2001:13-37. (Smoking and tobacco control monographs no. 13; NIH publication no. 025047)

54 Foster A. Synopsis of A.A. Foster's trip report: U.S.A., U.K., Switzerland, Nov. 1st-30th, 1974. 13 Feb 1975. Philip Morris. Bates No. 2024258828/ 8834 http://legacy.library.ucsf.edu/tid/gpl98e00

55 Wickham J. Saratoga 120 and Plus 120 cigarettes-Australia. 30 Oct 1975. Philip Morris. Bates No. 1000738157. http://legacy.library.ucsf.edu/tid/ $\mathrm{ss} \times 54 \mathrm{e} 00$

56 Balint L. Philip Morris Limited (Australia) C.I. report no. 38. May 1980. Philip Morris. Bates No. 2043841 206/1263. http://legacy.library.ucsf.edu/tid/ $\mathrm{kgo} 06 \mathrm{e} 00$

57 Evans G, Johnson G, Frizzell M. A study of the smoke yield of vented filter cigareftes. AGAL (unpublished manuscript), 1993.

58 Anti-Cancer Council of Victoria. Reducing tar content of cigarettes. Victorian Cancer News 1975:(No. 74):1.

59 US Department of Health and Human Services. The health consequences of smoking: the changing cigarette. A report of the Surgeon General, 1981. Rockville, Maryland: Public Health Service, Office of the Assistant Secretary for Health, Office on Smoking and Health, 1981. (DHHS Publication No (PHS) 81-50156).

60 Gray N. Low-tar cigarettes: bane or benefit. Cancer Detect Prev 1987;10:187-92

61 Gaisch H. Historical development. 11 Apr 1986. Philip Morris. Bates No. 2501004553/4556. http://legacy.library.ucsf.edu/tid/dxw29e00

62 de Weck R. Die Zeit (West Germany). Trouble over cigarettes: the firms BAT and Philip Morris are fighting over what is the best filter. 18 Nov 1983. Philip Morris. Bates No. 2025441886/1891. http://legacy.library.ucsf.edu/tid/ yxa56e00

63 Corner R. Barclay Australia. 11 Aug 1983. Philip Morris. Bates No. 2025443764. http://legacy.library.ucsf.edu/tid/fhf24e00

64 Anon. Fine cotton tricks win the tar derby. Choice 1985 Aug:6-8.

65 Mason W. Barclay-Australia. 2 Jun 1982. Brown \& Williamson. Bates No. 699129356/9358. http://legacy.library.ucsf.edu/tid/sdz50f00

66 Rehame Australia Monitoring Services Pty Ltd. Transcript of item broadcast on GTV9 A Current Affair 6. 30pm, 7th June 1993: Report on the cover up by the tobacco industry on the ventilation holes in cigarette filters and the dangers when these holes are blocked. 8 Jun 1993. Philip Morris. Bates No. 2028680693/0702. http://legacy.library.ucsf.edu/tid/gcp25e00

67 Choice. 'Low-tar' cigarettes: the real story. Aug 1993. Philip Morris. Bates No. 2046816666/6671. http://legacy.library.ucsf.edu/tid/ppm65e00 
68 Djordjevic MV, Fan J, Ferguson S, et al. Self-regulation of smoking intensity: smoke yields of the low-nicotine, low-'tar' cigarettes. Carcinogenesis 1995; 16:2015-21.

69 Diordjevic MV, Hoffmann D, Hoffmann I. Nicotine regulates smoking patterns. Prev Med 1997;26:435-40.

70 Borland R. Minimizing the harm from nicotine addiction. Aboriginal and Islander Health Worker Journal 1997;21:23-6.

71 Philip Morris (Australia) Limited. Key message book for representatives. Oct 1993. Philip Morris. Bates No. 2022810564/0570. http:// legacy.library.ucsf.edu/tid/dag35e00

72 Kozlowski LT, O'Connor RJ. Cigarette filter ventilation is a defective design because of misleading taste, bigger puffs, and blocked vents. Tobacco Control 2002;11(suppl I):i40-50

73 Shiffman S, Pillitteri JL, Burton SL, et al. Smokers' beliefs about "Light" and "Ultra Light" cigarettes. Tobacco Control 2001;10(suppl I):117-23.

74 British American Tobacco Australia. Smoking \& Health-Reducing the risks? Smoking less or lower delivery cigarettes. http://www.bata.com.au (Accessed 23 Sep 2003).

75 British American Tobacco Australia. Smoking \& Health-Smoking less or lower delivery cigarettes - What people should consider about smoking less or lower delivery products. http://www.bata.com.au (Accessed 23 Sep 2003).

76 Senate Community Affairs Reference Committee. The tobacco industry and the costs of tobacco-related illness. Canberra: The Committee, 1995

77 Philip Morris (Australia) Limited. Response to 'The Tobacco Industry and the Costs of Tobacco-Related Illness' report of the Senate Community Affairs References Committee. Jun 1996. Philip Morris. Bates No. 2063834649/ 4687. http://legacy.library.ucsf.edu/tid/zti32d00
78 Wooldridge M. [Letter to D. Staunton, Vice President, Corporate Affairs, Philip Morris Limited]. 18 Jun 1998. Philip Morris. Bates No. 2072523206/3207. http://legacy.library.ucsf.edu/tid/bqa06c00

79 Staunton D. [Letter to Michael Wooldridge, Minister for Health and Family Services]. 31 Jul 1998. Philip Morris. Bates No. 2064813389/3399. http:// legacy.library.ucsf.edu/tid/eua87d00

80 MacDonald J, Gray D. The Age, (Melbourne, Vic). Push to list tobacco additives. 27 Dec 1999. Philip Morris. Bates No. 2072522855/2856. http://legacy.library.ucsf.edu/tid/rza06c00

81 Department of Health. Draft voluntary agreement for the disclosure of the ingredients and emissions of cigarettes. 18 Apr 2000. Philip Morris. Bates No. 2072184460/4480. http://legacy.library.ucsf.edu/tid/xmq36c00

82 Department of Health. Voluntary agreement for the disclosure of the ingredients of cigarettes. Commonwealth Department of Health. 2000. http:// www.health.gov.au/pubhlth/strateg/drugs/tobacco/agreement.pdf (Accessed 23 Sep 2002).

83 Cannar N. Imperial Tobacco Australia Limited. Draft voluntary agreement for ingredient disclosure [Letter to S. Kerr, Dept. of Health]. 4 May 2000. Philip Morris. Bates No. 2075409963/9965. http://legacy.library.ucsf.edu/tid/ miq56c00

84 Windholz E. Tobacco Product Disclosure Roundtable Discussion, Friday, November 26, 1999. 29 Nov 1999. Philip Morris. Bates No. 2072523432/ 3437. http://legacy.library.ucsf.edu/tid/lta06c00

85 Department of Health. Australian cigarette emissions disclosure. http:// www.health.gov.au/pubhlth/strateg/drugs/tobacco/emmissions.htm (Accessed Jul 16 2003)

86 British American Tobacco Australia. Smoking \& Health-Reducing the risks? Research \& Development. http://www.bata.com.au (Accessed 16 Jul 2003). 